\title{
Assessing Predictors of Tamoxifen Nonadherence in Patients with Early Breast Cancer
}

\author{
Emilia Montagna' \\ Paola Zagami ${ }^{1,2}$ \\ Marianna Masiero ${ }^{3,4}$ \\ Ketti Mazzocco iD 3,4 \\ Gabriella Pravettoni (iD) 3,4 \\ Elisabetta Munzone (iD) \\ 'Division of Medical Senology, IEO \\ European Institute of Oncology IRCCS, \\ Milan, Italy; ${ }^{2}$ Division of Early Drug \\ Development for Innovative Therapies, \\ IEO European Institute of Oncology \\ IRCCS, Milan, Italy; ${ }^{3}$ Department of \\ Oncology and Hemato-Oncology, \\ University of Milan, Milan, Italy; ${ }^{4}$ Applied \\ Research Division for Cognitive and \\ Psychological Science, IEO European \\ Institute of Oncology IRCCS, Milan, \\ 20I4I, Italy
}

\begin{abstract}
Adjuvant endocrine therapy (AET) is generally proposed to all patients with hormone receptor-positive breast cancer to reduce the risk of recurrence and death. Adherence to therapy is crucial. However, non-adherence to AET is common, with estimates of up to $50 \%$ of patients not successfully completing a five-year course of treatment, and it is significantly associated with lower survival rates and a higher risk of recurrence. Currently, no gold standard is available to assess adherence. Several studies, most of them retrospective in nature, have used both direct and indirect methods to monitor the adherence to therapy in breast cancer. The indirect method is more widely used, and it is based on pharmacy prescription refills and patient administered questionnaires. On the other hand, direct methods such as a measurement of the level of the drug or its metabolites in blood or urine are much more precise, but more expensive and not routinely implemented. In this review, we analyzed the results of the major studies focused on the adherence to tamoxifen in breast cancer patients. We identified several factors associated with poor adherence, such as the side effects of therapy, the lack of shared decision-making between the physician and patient, the context in which the discussion takes place, and whether the patients are enrolled in a clinical trial. Moreover, we discussed possible methods to improve adherence to adjuvant therapy in breast cancer.
\end{abstract}

Keywords: adherence, adjuvant endocrine therapy, tamoxifen, breast cancer

\section{Introduction}

Poor adherence to medications is an international problem and is believed to lead to 200,000 premature deaths in Europe annually. ${ }^{1}$ This has had severe economic consequences, impacting the healthcare system, since patient non-adherence leads to additional medical treatments, emergency visits, and hospital admissions. ${ }^{2}$ Currently, the gold standard is not available to assess adherence. The International Society for Pharmacoeconomics and Outcomes Research (ISPOR) has focused on research into this unmet need, and has widened their definition of adherence to now include factors such as physiological and social issues. ${ }^{3}$ The World Health Organization (WHO) defines adherence as “the extent to which a person's behavior corresponds with agreed recommendations from a health care provider" underlining the need to consider varying factors, which may impact patient non-adherence. ${ }^{4}$ In breast cancer patients, adjuvant treatment is used to prevent the risk of recurrence. Currently, $75-80 \%$ of early-stage breast cancer patients are candidates for hormonal therapy, which may be continued for several years. ${ }^{5,6}$ Breast cancer prognosis has significantly improved over time, and the longer survival rates require dedicated strategies to manage long-term sequelae of breast cancer treatments. ${ }^{7}$ Therefore, adherence to therapy is of the utmost
Correspondence: Emilia Montagna Division of Medical Senology, European Institute of Oncology, IRCCS, Via Ripamonti 435, Milan, 20I4I, Italy $\mathrm{Tel}+390257489439$

Fax +3902574829212

Email emilia.montagna@ieo.it 
importance. Adjuvant endocrine therapy (AET) is generally proposed for all patients with endocrine-sensitive early breast cancer to reduce the risk of recurrence and death. Different options, including tamoxifen and aromatase inhibitors, with or without LHRH analogue (if premenopausal) should be discussed with the patients according to the stage and biological features of the breast cancer, concomitant disease, age, and patient preferences. ${ }^{8-11}$ Moreover, several data support that the prolongation of hormonal therapy (ie 10 years of hormonal treatment) is associated with a statistically improved outcome. ${ }^{12-15}$

All guidelines recommend that clinicians should consider adverse side effects, patient preferences, and pre-existing conditions when discussing adjuvant strategies in breast cancer. ${ }^{8}$

In order to monitor adherence to breast cancer therapy, both direct and indirect methods exist. The indirect method is more widely used, and it is based on pharmacy prescription refills and patient-administered questionnaires. This method may overestimate adherence, since patient self-reports can be particularly inaccurate, and pharmacy prescriptions do not necessarily reflect the true consumption of medication, since patients may collect their treatment and not actually take them. On the other hand, direct methods, such as a measurement of the level of the drug or its metabolites in blood or urine, are much more precise, but more expensive and not routinely implemented.

Several studies have attempted to analyze adherence in breast cancer patients. The majority are retrospective and use an indirect method to identify non-adherence. These studies aimed to understand factors related to nonadherence in endocrine therapy. The percentage of nonadherence changed between studies, and ranged between $30 \%-60 \%{ }^{16-21}$

The aims of this review were to analyze factors associated with poor adherence to tamoxifen and to discuss possible methods to improve adherence to adjuvant therapy in breast cancer.

\section{Methods}

We conducted a review of the results of retrospective and prospective studies testing the adherence to tamoxifen in breast cancer patients. The Medline database was searched for fully published articles using the keywords 'adherence to tamoxifen' and 'non-adherence to tamoxifen' and 'cancer' or 'breast'. The search was restricted to the English language. Exclusion criteria included the following: pediatric trials, studies referring to adherence in the metastatic breast cancer setting, editorials, case reports and review articles. For studies with multiple presentations and/or publications, only the latest versions were included in the analysis.

\section{Studies of Adherence to Tamoxifen and Aromatase Inhibitors in Breast Cancer \\ Patients}

Table 1 reports the studies focused on the adherence to tamoxifen.

Historically, the first study by Partridge et al retrospectively evaluated the adherence of 2378 breast cancer patients to tamoxifen, defined as the availability of tamoxifen for more than $80 \%$ of their first year of prescribed therapy. The authors reported that $23 \%$ of women were classified as non-adherent, and factors related to the poor adherence were the extremes of age (either very young with age less than 45 years, or very old, $\geq 85$ years), nonwhite ethnicity, the type of surgery, and the absence of discussion with oncologist. ${ }^{22}$

Van Herk-Sukel et al retrospectively studied 1451 patients treated with adjuvant tamoxifen. A total of $30 \%$ of the population discontinued treatment at two years, evaluated as failure to provide a prescription. Associated factors were found to be older age (older than 70), and the presence of two or more comorbidities. ${ }^{23}$

The same method to evaluate discontinuation of tamoxifen was also used by Hershman et al in 8769 patients with breast cancer. ${ }^{24}$ The authors found that $30 \%$ were defined as non-adherent to tamoxifen at four years. Similar factors, such as the presence of more comorbidities, extreme ages and the type of surgery, were found to be associated with AET discontinuation.

Similar results were reported by Cavazza et al in a larger retrospective analysis of real-world data of 33,921 surviving women starting AET in 2010-2016. Factors associated with negative determinants of adherence to AET (identified with filled prescriptions of AET for $>292 / 365$ days) were as follows: a delayed initiation of treatment after surgery, receiving surgery in a high-volume hospital, and depression status. ${ }^{25}$ The type of AET was associated with different adherence behavior; women treated with tamoxifen had a reduction of $31 \%$ of adherence at five years compared with those who switched therapies. The adherence rate decreased with a longer follow up, and if women did not receive adjuvant chemotherapy. 
Table I Studies of Adherence to Tamoxifen in Breast Cancer Patients

\begin{tabular}{|c|c|c|c|c|c|}
\hline Authors & $\begin{array}{l}\text { Patients } \\
\text { (N) }\end{array}$ & $\begin{array}{l}\text { FUP } \\
\text { Period }\end{array}$ & Nonadherence Definition & $\begin{array}{l}\text { Results in } \\
\text { Terms of } \\
\text { Nonaderence }\end{array}$ & Associated factors to Nonadherence \\
\hline $\begin{array}{l}\text { Demissie, } \\
2001^{56}\end{array}$ & 303 & 3 yrs & Self-report survey data & $15 \%$ & Side effects \\
\hline $\begin{array}{l}\text { Partrige, } \\
2003^{22}\end{array}$ & 2378 & 4 yrs & $\begin{array}{l}\text { Number of days covered by filled } \\
\text { prescriptions for tamoxifen in the } \\
\text { first year of therapy }<80 \%\end{array}$ & $23 \%$ at I $\mathrm{yr}$ & $\begin{array}{l}\text { Extremes of age; patients less than } 45 \text { and } 85 \text { years; } \\
\text { Nonwhite; mastectomy rather than breast-conserving } \\
\text { surgery; NOT seen an oncologist in the year before beginning } \\
\text { tamoxifen therapy }\end{array}$ \\
\hline Fink, $2004^{38}$ & 516 & 2 yrs & Self-report survey data & $17 \%$ & $\begin{array}{l}\text { Neutral or negative beliefs about the value of tamoxifen; } \\
\text { positive nodes }\end{array}$ \\
\hline $\begin{array}{l}\text { Grunfeld, } \\
2005^{57}\end{array}$ & 110 & na & Self-report survey data & $46 \%$ & $\begin{array}{l}\text { Side effects, change of routine, belief that there was nothing } \\
\text { to be gained from taking tamoxifen }\end{array}$ \\
\hline $\begin{array}{l}\text { Lash, } \\
2006^{26}\end{array}$ & 462 & 5 yrs & $\begin{array}{l}\text { Self-report survey data. Failed to } \\
\text { complete the recommended 5-year } \\
\text { course }\end{array}$ & $31 \%$ & Severe side effects, added a prescription \\
\hline $\begin{array}{l}\text { Kahn, } \\
2007^{40}\end{array}$ & 881 & $4 \mathrm{yrs}$ & Self-report survey data & $21 \%$ & Older age and the severity of side effects \\
\hline $\begin{array}{l}\text { McCowan, } \\
2008^{30}\end{array}$ & 1633 & 3 yrs & $\begin{array}{l}\text { Percentage of days covered by all the } \\
\text { prescriptions for each patient dividing it by } \\
\text { the duration }\end{array}$ & $\begin{array}{l}10 \% \text { at } \mathrm{I} \mathrm{yr} \\
19 \% \text { at } 2 \mathrm{yrs} \\
32 \% \text { at } 3 \mathrm{yrs}\end{array}$ & Younger women were more likely to have low adherence \\
\hline $\mathrm{Ma}, 2008^{58}$ & 788 & na & $\begin{array}{c}\text { Not taking as recommended or take }< \\
\text { lyear }\end{array}$ & $30 \%$ & Younger age \\
\hline $\begin{array}{l}\text { Owusu, } \\
2008^{59}\end{array}$ & 961 & 5 yrs & $\begin{array}{l}\text { Discontinuing tamoxifen for more than } \\
\qquad 60 \text { day }\end{array}$ & $\begin{array}{l}15 \% \text { at } 1 \mathrm{y}, 24 \% \\
\text { at } 2 \mathrm{yrs}, 33 \% \text { at } \\
3 \mathrm{yrs}\end{array}$ & $\begin{array}{c}<70 \text { years or >or }=80 \text { years; breast-conserving surgery }(\mathrm{BCS}) \\
\text { without radiotherapy; increase in the number of } \\
\text { cardiopulmonary comorbidities at } 3 \text { years }\end{array}$ \\
\hline Rae, $2009^{60}$ & 280 & I yr & Not complete 4 months of therapy & $14 \%$ & $\begin{array}{l}\text { Active CYP2D6 alleles may predict for higher likelihood of } \\
\text { tamoxifen discontinuation }\end{array}$ \\
\hline $\begin{array}{l}\text { van Herk- } \\
\text { Sukel, } \\
2010^{23}\end{array}$ & $|45|$ & $5 \mathrm{yrs}$ & $\begin{array}{l}\text { Taking the drug during a specific period of } \\
\text { time (I-5 yrs) without failure to continue } \\
\text { renewals }\end{array}$ & $\begin{array}{l}17 \% \text { at } I \mathrm{yr} \\
30 \% \text { at } 2 \mathrm{yrs} \\
45 \% \text { at } 3 \mathrm{yrs}\end{array}$ & $\begin{array}{l}\text { Older age (older than } 70 \text { versus 50-69 years); two or more } \\
\text { concomitant diseases (versus no comorbidity) }\end{array}$ \\
\hline $\begin{array}{l}\text { Dezentje, } \\
2010^{61}\end{array}$ & 1962 & 6 yrs & $\begin{array}{l}\text { The proportion of days (percentage) } \\
\text { covered by tamoxifen in the first year } \\
\text { following tamoxifen initiation }<80-90 \%\end{array}$ & $\begin{array}{c}\text { Mean of } 16 \% \text { at } \\
3 \text { yrs }\end{array}$ & $\begin{array}{l}\text { Not effect of concomitant CYP2D6 inhibitor use during } \\
\text { tamoxifen therapy }\end{array}$ \\
\hline $\begin{array}{l}\text { Thompson, } \\
2011^{62}\end{array}$ & 257 & na & Medication Possession Ratio (MPR) $<80 \%$ & $14 \%$ & na \\
\hline $\begin{array}{l}\text { Huiart, } \\
2012^{63}\end{array}$ & 246 & 3 yrs & Medication Possession Ratio (MPR) $<80 \%$ & $\begin{array}{l}17 \% \text { at } 1 \mathrm{yr} \\
29.7 \% \text { at } 2 \mathrm{yrs} \\
39.5 \% \text { at } 3 \mathrm{yrs}\end{array}$ & Low social support and self-reporting of non-compliance \\
\hline $\begin{array}{l}\text { Pistilli, } \\
2020^{32}\end{array}$ & 1177 & 3 yrs & $\begin{array}{l}\text { Self-declared /biochemical measuring } \\
\text { tamoxifen-serum }<60 \mathrm{ng} / \mathrm{mL}\end{array}$ & $16 \% / 12 \%$ & $\begin{array}{l}\text { Side effects, not receiving neoadjuvant chemotherapy, non- } \\
\text { partnered living }\end{array}$ \\
\hline
\end{tabular}

Lash et al used a different methodology to analyze adherence. They interviewed 462 patients with breast cancer to evaluate the continued use of tamoxifen. ${ }^{26}$
Of the entire cohort, $31 \%$ of enrolled women did not manage to conclude the five years of adjuvant tamoxifen prescribed. 
In the small study conducted by Brett et al referred to 32 women (19 adherers and 13 non-adherers) who were interviewed after two or four years of AET, the factors associated with non-adherence to AET were the impact of side effects on their quality of life. Other factors were a feeling of lack of support (mostly when they switched the follow-up from the hospital to their general physician (GP)), unawareness of the risk of recurrences, and of the benefits of AET. Moreover, some women declared that they had interrupted adjuvant therapy to return to normality. ${ }^{27}$

A total of 100 women interviewed by Ziller et al declared full adherence to tamoxifen or aromatase inhibitors, but, after studying prescriptions, $20 \%$ of patients resulted non-adherent to tamoxifen. No baseline factors were related to discontinuation. ${ }^{28}$

Different factors related to adherence were identified using prospective studies that were designed in more recent years. Wassermann et al prospectively studied nonadherence behaviors to AET in women under 40 years of age with breast cancer at 30 months, after the initiation of adjuvant endocrine therapy. Patients were evaluated using indirect methods based on three items of poor adherence (ie forgetting to take ET, stopping ET due to feeling unwell, and not having taken therapy in the manner suggested by their doctor in the last three months). More than half $(51 \%)$ of 384 enrolled patients declared at least one among the three mentioned non-adherence behaviors. A low educational level, low social support, and low confidence in adjuvant ET were factors associated with non-adherence to ET. The most common cause of nonadherence was forgetting to take the pills. ${ }^{29}$

Table 2 reports the studies focused on the adherence to tamoxifen and aromatase inhibitors.

The study by Yusufov et al attempted to identify predictor factors related to increased risk of non-adherence to AET. A total of 73 women were enrolled before starting AET, assessing psychological and menopausal symptoms at time 0 , after 3 and 6 weeks of AET. In this study, the adherence was also evaluated using indirect methods and, from the selfdeclaration of treatment adherence, only $20 \%$ and $26 \%$ of women were non adherents at 3 and 6 weeks of starting AET, respectively. ${ }^{30}$ Unlike previous studies, no statistically significant difference regarding race, marriage, and employment status was identified to explain adherence and nonadherence amongst women. The majority of non-adherent women described depressive symptoms pre-AET that could contribute as an important predictor factor to non-adherent behavior to AET.

He et al found different predictor factors for discontinuation of AET in 3395 women who started adjuvant therapy with tamoxifen or aromatase inhibitors. ${ }^{31}$ Among these predictors, the major baseline factors were not only the use of antidepressant drugs but also hypnotics, gastrointestinal drugs, and switching therapy to aromatase inhibitors.

Recently, non-adherence to tamoxifen was examined by serum assessment in 1177 French premenopausal patients within the CANTO trial in the first year after the start of adjuvant endocrine treatment. ${ }^{32}$ The authors also evaluated the patients' self-declaration of adherence or non-adherence with related reasons and studied its impact on short-term breast cancer survival outcomes. After a median follow-up of 24.2 months since tamoxifen serum assessment, patients who were biochemically nonadherent had significantly shorter DDFS (for distant recurrence or death, adjusted hazard ratio, 2.31; $95 \%$ CI, 1.05 to 5.06 ; P 5 0.036), with $89.5 \%$ of patients alive without distant recurrence at 3 years in the nonadherent cohort versus $95.4 \%$ in the adherent cohort.

The two methods were significantly associated but with moderate concordance. Biochemical methods and indirect methods identified $16 \%(188 /)$ and $12 \%$ (145) of patients as non-adherent, respectively. Only $50 \%$ of self-declared nonadherent patients explained their reasons for discontinuation, which in the majority of cases was due to tamoxifen-related side effects. Similarly to other chronic diseases, social factors were associated with non-adherence to adjuvant treatment, such as non-partnered living. Moreover, increased risk of non-adherence was associated with the onset of symptoms related to tamoxifen. In addition, not receiving neoadjuvant chemotherapy, which is believed to be associated with a decreased awareness of the risk of non-adherence and the gravity of their situation, is another factor found to impact non-adherence. Other studies also found similar results in patients not previously receiving chemotherapy.

\section{Studies on Psycho-Social Processes Underlying Non-Adherence to Tamoxifen on Breast Cancer Patients}

Several studies affirmed that medication non-adherence should be considered as a multi-level concept, and should not be reduced exclusively to clinical (eg, disease and treatments), socio-demographic (eg, age, gender, socioeconomic status) and health system-related factors, but also individuals' psychological characteristics should be 
Table 2 Studies of Adherence to Tamoxifen and Other Endocrine Therapies in Breast Cancer Patients

\begin{tabular}{|c|c|c|c|c|c|}
\hline Authors & $\begin{array}{l}\text { Patients } \\
\text { (N) }\end{array}$ & $\begin{array}{l}\text { FUP } \\
\text { Period }\end{array}$ & Nonadherence Definition & $\begin{array}{c}\text { Results in } \\
\text { Terms of } \\
\text { Nonadherence }\end{array}$ & Associated Factors to Nonadherence \\
\hline Guth, $2008^{51}$ & 287 & 5 yrs & $\begin{array}{l}\text { Discontinued the planned mode } \\
\text { of treatment and refused to } \\
\text { continue further endocrine } \\
\text { therapy. }\end{array}$ & $11 \%$ & $\begin{array}{l}\text { Follow-up with a general practitioner and } \\
\text { adverse events }\end{array}$ \\
\hline $\begin{array}{l}\text { Kimmick, } \\
2009^{64}\end{array}$ & |49| & I yr & $\begin{array}{l}\text { Medication Possession Ratio } \\
(\mathrm{MPR})<80 \%\end{array}$ & $20 \%$ & Married status \\
\hline $\begin{array}{l}\text { Schwartzberg, } \\
2009^{65}\end{array}$ & 200 & na & Self-report survey data & $20 \%$ & Musculoskeletal symptoms \\
\hline Ziller, $2009^{28}$ & 100 & I yr & $\begin{array}{l}\text { Medication Possession Ratio } \\
(\mathrm{MPR})<80 \%\end{array}$ & $20 \% \operatorname{tam} 30 \% \mathrm{Al}$ & Nothing \\
\hline $\begin{array}{l}\text { Dittmer, } \\
2011^{66}\end{array}$ & & 5 yrs & Self-report survey data & $23 \%$ & Side-effects \\
\hline Guth, 2011 ${ }^{67}$ & 427 & $\mathrm{l} \mathrm{yr}$ & Discontinued therapy in 5 yrs & $9 \%$ & Side effects \\
\hline $\begin{array}{l}\text { Nekhlyudov, } \\
2011^{68}\end{array}$ & 2207 & $3 \mathrm{yr}$ & $\begin{array}{l}\text { Medication Possession Ratio } \\
(\mathrm{MPR})<80 \%\end{array}$ & $21 \%$ at $\mathrm{I} y \mathrm{rs}$ & Age $\geq 70$ years \\
\hline $\begin{array}{l}\text { Hershman, } \\
20 \mathrm{II}^{24}\end{array}$ & 8769 & 4 yrs & $\begin{array}{l}\text { Medication Possession Ratio } \\
(\mathrm{MPR})<80 \%\end{array}$ & $28 \%$ & $\begin{array}{l}\text { Younger or older age and an increased number } \\
\text { of comorbidities }\end{array}$ \\
\hline Huiart, 201 $1^{63}$ & 13,479 & 5 yrs & $\begin{array}{l}\text { Medication Possession Ratio } \\
(\mathrm{MPR})<80 \%\end{array}$ & $29 \%$ at 5 yrs & Side effects, younger women, use of tamoxifen \\
\hline $\begin{array}{l}\text { Wigertz, } \\
2012^{69}\end{array}$ & $174 \mid$ & 3 yrs & $\begin{array}{l}\text { Medication Possession Ratio } \\
(\mathrm{MPR})<80 \%\end{array}$ & $31 \%$ & Unmarried women, switching therapy \\
\hline $\begin{array}{l}\text { Weaver, } \\
2012^{70}\end{array}$ & 857 & 5 yrs & $\begin{array}{l}\text { Medication Possession Ratio } \\
(\mathrm{MPR})<80 \%\end{array}$ & $18 \%$ at I $\mathrm{yr}$ & $\begin{array}{l}\text { Studied effect of concomitant use of CYP2D6 } \\
\text { enzyme inhibitor medications }\end{array}$ \\
\hline $\mathrm{He}, 2015^{31}$ & 3395 & 5 yrs & $\begin{array}{l}\text { Having any interval between two } \\
\text { consecutive dispenses exceeding } \\
180 \text { days during the follow-up }\end{array}$ & $50 \%$ & $\begin{array}{l}\text { Use of antidepressant, hypnotics, gastro- } \\
\text { intestinal drugs and switching therapy to } \\
\text { aromatase inhibitors }\end{array}$ \\
\hline Brett, $2018^{27}$ & 32 & 4 yrs & Self-report survey data & $13 / 32$ & $\begin{array}{l}\text { Side effects, feeling of unsupported, } \\
\text { unawareness of the risk of recurrences and of } \\
\text { the benefits of } A E T\end{array}$ \\
\hline $\begin{array}{l}\text { Wasserman, } \\
2019^{29}\end{array}$ & 384 & $2,5 \mathrm{yrs}$ & Self-report survey data & $51 \%$ & $\begin{array}{l}\text { A low educational level, low social support and } \\
\text { low- confidence about adjuvant }\end{array}$ \\
\hline $\begin{array}{l}\text { Yusufov, } \\
2020^{30}\end{array}$ & 73 & 6 ws & Self-report survey data & $26 \%$ & Pre-existing depressive symptoms \\
\hline $\begin{array}{l}\text { Cavazza, } \\
2020^{25}\end{array}$ & 8400 & 5 yrs & $\begin{array}{l}\text { Medication Possession Ratio } \\
(\mathrm{MPR})<80 \%\end{array}$ & $18 \%$ & $\begin{array}{l}\text { Age } \geq 70 \text { years, delayed initiation of treatment } \\
\text { after surgery, receiving surgery in a high-volume } \\
\text { hospital and depression status, not receive } \\
\text { chemotherapy }\end{array}$ \\
\hline
\end{tabular}


Table 3 Studies on Psycho-Social Processes Underlying Non-Adherence to Tamoxifen

\begin{tabular}{|c|c|c|c|c|c|c|c|c|}
\hline Authors & Year & $\begin{array}{l}\text { Type of } \\
\text { Study }\end{array}$ & $\begin{array}{l}\text { Patients } \\
\text { (N) }\end{array}$ & $\begin{array}{l}\text { Disease } \\
\text { Stage }\end{array}$ & FUP Period & $\begin{array}{c}\text { Nonadherence } \\
\text { Measure }\end{array}$ & $\begin{array}{c}\text { Nonadherence } \\
\text { Rate }\end{array}$ & $\begin{array}{c}\text { Psychological Processes } \\
\text { Associated to } \\
\text { Nonaadherence }\end{array}$ \\
\hline Cahir et al. ${ }^{33}$ & 2015 & Qualitative & 31 & $I^{\circ}-110^{\circ}$ & 3 Months & Interview & $73 \%$ & $\begin{array}{l}\text { Self-monitoring; } \\
\text { Environmental stressors; } \\
\text { Knowledge; Medication } \\
\text { Beliefs; Time Perspective }\end{array}$ \\
\hline $\begin{array}{l}\text { Corter } \\
\text { et al. }{ }^{71}\end{array}$ & 2018 & Survey & 125 & $1^{\circ}$ & 3 Months & Pill count & $36 \%$ & Health Beliefs \\
\hline Cluze et al. ${ }^{39}$ & 2012 & Prospective & 218 & $\begin{array}{c}\text { Not } \\
\text { available }\end{array}$ & $\begin{array}{l}10,16 \text {, and } \\
28 \text { months }\end{array}$ & $\begin{array}{l}\text { Two or more consecutive } \\
\text { months without } \\
\text { dispensed prescription of } \\
\text { tamoxifen }\end{array}$ & $42 \%$ & $\begin{array}{l}\text { Fear of recurrence; Social } \\
\text { Support; Patient-Doctor } \\
\text { Communication; treatment } \\
\text { options }\end{array}$ \\
\hline Fink et al. ${ }^{38}$ & 2004 & Cohort & 516 & $I^{\circ}-11 I^{\circ}$ & $\begin{array}{l}3,6,15 \text {, and } \\
27 \text { months }\end{array}$ & Interview & $21 \%$ & Medication Beliefs \\
\hline Khan et al. ${ }^{40}$ & 2007 & Cohort & 881 & $I^{\circ}-11 I^{\circ}$ & 4-yeras & Single item & $21 \% \%$ & $\begin{array}{l}\text { involvement in decision- } \\
\text { making }\end{array}$ \\
\hline Liu et al. ${ }^{41}$ & 2013 & Prospective & 303 & $I^{\circ}-1 I I^{\circ}$ & $\begin{array}{l}6,18 \text {, and } 36 \\
\text { months }\end{array}$ & Single item & $36 \%$ & $\begin{array}{c}\text { Patient-centered } \\
\text { communication; Self-efficacy }\end{array}$ \\
\hline Moon et al. ${ }^{36}$ & 2019 & Longitudinal & 345 & $1^{\circ}-1111^{\circ}$ & $\begin{array}{c}3,6 \text { and } 12 \\
\text { months }\end{array}$ & $\begin{array}{c}\text { Medication Adherence } \\
\text { Rating Scale }\end{array}$ & $50 \%$ & $\begin{array}{l}\text { Medication beliefs/Self- } \\
\text { Confidence in ability to take } \\
\text { tamoxifen }\end{array}$ \\
\hline Moon et al. ${ }^{34}$ & 2017 & $\begin{array}{l}\text { Cross- } \\
\text { sectional }\end{array}$ & 777 & $I^{\circ}-1 I^{\circ}$ & $\mathrm{I}-2$ years & $\begin{array}{l}\text { Medication Adherence } \\
\text { Report Scale }\end{array}$ & $44 \%$ & Medication Beliefs \\
\hline Pan et al. $^{37}$ & 2018 & Cohort & 116 & $I^{\circ}-110^{\circ}$ & At 24 months & Single item & $14.7 \%$ & Medication Beliefs/Optimism \\
\hline $\begin{array}{l}\text { Vaughn } \\
\text { et al. }{ }^{35}\end{array}$ & 2020 & Prospective & 89 & $\begin{array}{c}\text { Not } \\
\text { available }\end{array}$ & Not available & Pill count & Not available & Delay discounting effect \\
\hline $\begin{array}{l}\text { Wassermann } \\
\text { et al. }{ }^{29}\end{array}$ & 2019 & Cohort & 384 & $I^{\circ}-111^{\circ}$ & At 30 months & Three-item & $51 \%$ & $\begin{array}{c}\text { Social-support/Confidence in } \\
\text { Decision-Making }\end{array}$ \\
\hline $\begin{array}{l}\text { Wheeler } \\
\text { et } \text { al. }^{47}\end{array}$ & 2019 & Cohort & 1280 & $I^{\circ}-11 I^{\circ}$ & $\begin{array}{l}\text { 2-years post- } \\
\text { diagnosis-10 } \\
\text { years post- } \\
\text { diagnosis }\end{array}$ & Two-item & $18.9 \%$ & Recurrence risk perception/ \\
\hline $\begin{array}{l}\text { Yusufov } \\
\text { et al. }{ }^{30}\end{array}$ & 2021 & Prospective & 73 & $1^{\circ}-11^{\circ}$ & 3-6 weeks & Two-item & $77.9 \%$ & $\begin{array}{c}\text { Anxiety/Depression/ } \\
\text { Somatosensory Amplification }\end{array}$ \\
\hline
\end{tabular}

included in the explanatory model ${ }^{33,34}$ (Table 3) Commonly, the individual factors refer to a set of psychological and relational processes, such as health beliefs (beliefs about medications, illness susceptibility), emotional wellbeing (anxiety, depression and fear of recurrence), self-efficacy, time perspective, social support, patient-doctor relationship and the patient's role in clinical decision-making throughout the disease pathway All mentioned factors seem to boost both intentional and unintentional non-adherence in ET and AET. ${ }^{30,35}$
Patients' Beliefs and Dispositional Characteristics

Many studies conveyed that modulators of adherence were connected to individual beliefs about medications (belief of medication effectiveness vs distrust toward the medication) and illness susceptibility. ${ }^{36,37}$ A qualitative study conducted by Cahir et al showed that a general mistrust of drugs increased the risk of non-adherence. As for endocrine treatments, Fink et al in a longitudinal study on 516 patients with ER-positive tumors reported that $17 \%$ of women stopped taking tamoxifen during the 2-year follow-up stage due to 
the negative beliefs associated with risks and benefits of tamoxifen. ${ }^{33,38}$ More specifically, women were more adherent to tamoxifen when the benefits of the treatment were perceived as outweighing the risks, compared to women who perceived the risks as similar or higher than the benefits As Cahir et al suggested, nonadherent women seem to attribute a higher value to quality of life than to an increased life expectancy. Authors argued that the expectation of treatment side effects reinforces the tendency to search for confirmatory symptoms. In addition, the prescription of further drug treatments to control side effects might have the paradoxical effect of diminishing motivation to start or continue with treatment. Furthermore, Pan et al conducted a cohort study on 116 women with hormone receptor-positive breast cancer or a ductal carcinoma in situ undergoing AET, measuring psychological predictors of adherence at 2-years. ${ }^{37}$ The results identified a significant role of optimism and emotional wellbeing (anxiety and depression). In particular, compared to nonadherent women, adherent women reported lower anxiety and depression, higher drug effectiveness beliefs, lower expected side-effect severity and higher level of optimism. In addition, perceived self-efficacy in handling the expected side-effects was able to affect adherence behavior more than side effects per se. Analogous results were found by Moon et al observing that nonadherent women were more likely to perceive a lower self-confidence in managing the treatment. $^{36}$

\section{Patients' Preferences and Relational Factors}

Two other key variables that affect adherence rate to tamoxifen are connected with a lower involvement in the treatment decisions and patient-doctor relationship. ${ }^{29,39}$ Indeed, as reported by Wassermann et al the role (active, passive or collaborative) of women in clinical decisions and their confidence with the decision regarding ET are moderators of adherence. More specifically, lack of shared decision-making between patients and their oncologist and a lower confidence toward the decided treatment were associated with a lower adherence. Accruing evidence suggested that women who feel that their needs and values are recognized, and that their preferences are integrated in the clinical decisions, are more prone to adhere to the prescribed treatment. Similar results were sustained by other studies that, in addition, showed that a poor patient-doctor relationship at the time of diagnosis, as well as a low quality of treatment-related information provided by the oncologist were significantly related to non-adherence ${ }^{40}$ Also, Liu et al highlighted that patient- centered communication was positively associated with tamoxifen persistence at three years post-diagnosis ${ }^{41}$

\section{Patients' Emotional Predictors}

Moreover, negative emotions connected to disease onset and/or which arise along the care pathway may have a strong incidence on non-adherence. For example, a qualitative study on women with stage I-III breast cancer treated with adjuvant hormonal therapy found that the fear of cancer recurrence was negatively related to nonadherence. Mainly, young breast cancer survivors with lower fear of recurrence are at increased risk of interrupting tamoxifen. In keeping with this, Cluze et al reported that at 16-28 months after the breast cancer diagnosis, the fear of recurrence was negatively associated with AET interruption. This effect was particularly evident in women with poor knowledge of the risk of breast cancer recurrence and the benefits associated with the AET. ${ }^{39}$

\section{Patients' Time Perspective}

Chair et al highlighted the importance of the time perspective, that is the tendency to orient thoughts, attitudes and actions toward the present (present orientation attitude) or toward the future (future orientation attitude). As Chair et al showed, nonadherent women had a present orientation, focusing attention on events and facts that are close in time, leading them to avoid side-effects and undesired lifestyle changes that treatments might require, and underweighting the long-term negative effect of non-adherence. By contrast, adherent women demonstrated a future-oriented time perspective, and were more focused on the avoidance of breast cancer recurrence, using a wide range of coping strategies to manage the current negative effects. Thus, adherence is supported by future positive outcomes, rather than immediate pleasure. Consistently with the time perspective, some studies (eg, Vaughn et al 2020) have also hypothesized that adherence might be associated with psychological processes, such as devaluation of delayed outcomes. Investigators conducted a study on breast cancer survivors who had been prescribed AET, and adherence was assessed by pill count and selfreport. Results revealed that nonadherent women have a high level of delay discounting: they tend to discount the value of the benefits related to the ET as a function of time. ${ }^{35}$

\section{Discussion}

Non-adherence to tamoxifen therapy is a difficult topic to evaluate. The lack of a gold standard by which to identify non-adherence, and the absence of standard methods to 


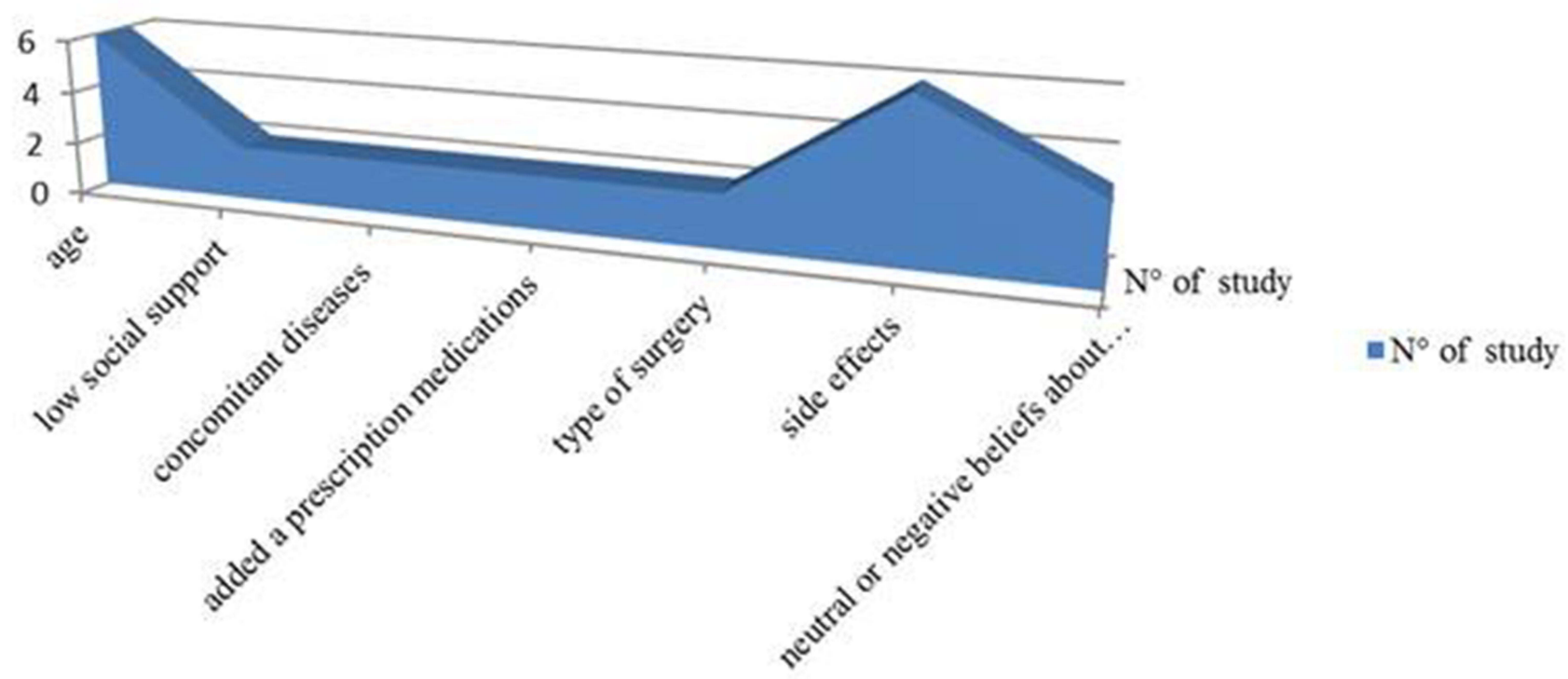

Figure I Factors associated to non-adherence to Tamoxifen in breast cancer patients.

improve adherence make it particularly challenging to perform studies. Despite differences in methodology, various studies have identified the importance of dialogue between the oncologist and patients in order to emphasize the magnitude of the benefits of AET leading to an increased adherence to medication (Figure 1).

Investigating the preferences of patients is important because the preferences could affect the adherence to treatments. Non-adherence to AET is common, with estimates of up to $50 \%$ of patients not successfully completing a 5 -year course of treatment. ${ }^{42,43}$

Moreover, non-adherence to breast cancer treatment is significantly associated with lower survival rates and a higher risk of recurrence, as was recently reported in the CANTO trial, where patient self-reports underestimated rates of non-adherence and $55 \%$ of patients who were nonadherent by serum assessment might not overtly acknowledge non-adherence. ${ }^{32,44-46}$ Furthermore, nonadherence by serum assessment measured as early as year 1 after treatment prescription emerged as marker of poorer outcomes regardless of other main prognostic factors, suggesting that risk of recurrence increases as soon as the patients start to be nonadherent. The implications of these results highlight that patients are less aware of the health risks related to their disease and misconceive the beneficial impact of adjuvant endocrine therapy on breast cancer outcomes.

Wheeler et al found that there is a correlation between a lack of shared decision-making and non-adherence in a cross-sectional survey from the Carolina Breast Cancer Study. ${ }^{47}$

Preliminary findings from the Breast Cancer Quality of Care (BQUAL) study measuring factors associated with initiation of hormonal therapy suggest that the way patients view hormonal treatment significantly impacts the likelihood of adherence. ${ }^{48}$ Those with negative beliefs were found to be far less willing to commence treatment. Conversely, those with more positive opinions, and those given the chance to communicate and ask questions about their treatment, had a higher probability of undertaking and continuing treatment.

In addition, an effective physician-patient relationship will allow patients to understand potential side effects and give them the ability to manage side effects more effectively. Indeed, one of the main reasons for discontinuation of therapy is due to the collateral effects. Menopausal symptoms are the most common side effects of AET and require a complex coordination of care. In premenopausal women, hormonal therapy can have an impact on fertility, and alter plans for childbearing. Physical changes may be noticed by patients as well as alterations in sexual function.

In the ELENA study, focused on the preferences of patients regarding hormonal therapy, almost $40 \%$ of patients reported side effects of severe grade, such as joint pain, vaginal dryness, and loss of libido. ${ }^{49}$ In order to improve the management of side effects, patient interactive digital applications are an area of developing research. Interactive digital support could be implemented in order to monitor the compliance to therapy as well as the side effects. ${ }^{50}$ 
Another factor that could affect adherence is the context where the discussion is conducted and if the patients are enrolled in a clinical trial. A discrepancy in the ranges of discontinuation rates was reported in clinical practice settings (31-73\%) compared with clinical trials $(8-28 \%) .{ }^{51-53}$ In the setting of a clinical trial, patients are supervised more closely, with more frequent appointment dates, which may make it easier to monitor adherence to therapy. Outside the setting of a clinical trial, it is common for patients to receive suboptimal follow-up care. Evidence from the 2009 Behavioral Risk Factor Surveillance System (BRFSS) shows that only $20 \%$ of all cancer survivors continue to use an oncologist or cancer specialist as their primary provider for cancer follow-up care. ${ }^{54}$ It may be of importance for a patient to continue seeing a physician in order to ensure they are receiving appropriate care.

Since 2020, the rapid spread of COVID-19 infection made the interaction between oncology patients and physicians more challenging. During the COVID-19 pandemic, a statistically significant reduction in emotional functioning was observed in patients with breast cancer. Patients developed worse anxiety, depression, and distress, all of which were important factors for non-adherence to hormonal therapy. In this particularly difficult time, telemedicine was used in order to overcome this problem and ensure doctors were still in frequent contact with their patients. $^{55}$

In line with this perspective, an integrated model combining the characteristics of patients, disease, patient approach, and health system would be highly recommended to provide new decision-making and intervention strategies. Such an approach may be useful in reducing patient and health system costs related to non-adherence.

In addition, empowering patients to take control over their care goes a long way to improving healthcare quality. For instance, a high level of medication adherence leads to lower disease-related medical costs. However, nonadherence rates when linked to poor clinical outcomes may increase hospital admissions and healthcare costs.

In conclusion, projects based on real-world data, that aim to identify factors for non-adherence to hormonal therapy should be warranted, in the hope that we can increase awareness and adherence to these medications for our patients.

\section{Disclosure}

Drs Elisabetta Munzone reports advisory roles for Pierre Fabre, Genomic Health, and Eisai, and travel grants from
Roche and Pfizer, outside the submitted work. The authors report no other potential conflicts of interest for this work.

\section{References}

1. Lemstra M, Nwankwo C, Moraros BY. Primary nonadherence to chronic disease medications: a meta-analysis. $J$ Patient Prefer Adherence. 2018;12:721-731. doi:10.2147/PPA.S161151

2. McHorney CA, Schousboe JT, Cline RR, Weiss TW. The impact of osteoporosis medication beliefs and side-effect experiences on non-adherence to oral bisphosphonates. Curr Med Res Opin. 2007;23:3137-3152. doi:10.1185/030079907X242890

3. Mohiuddin AK. Risks and reasons associated with medication non-adherence. J Clin Pharm. 2019;1:50-53.

4. Kardas P, Aguilar-Palacio I, Almada M, et al. The need to develop standard measures of patient adherence for big data: viewpoint. Med Internet Res. 2020;22:1-11.

5. Early Breast Cancer Trialists' Collaborative Group. Effects of chemotherapy and hormonal therapy for early breast cancer on recurrence and 15-year survival: an overview of the randomised trials. Lancet. 2005;365:1687-1717. doi:10.1016/S0140-6736(05)66544-0

6. The Early Breast Cancer Trialists' Collaborative Group. Relevance of breast cancer hormone receptors and other factors to the efficacy of adjuvant tamoxifen: patient-level meta-analysis of randomised trials. Lancet. 2011;378:771-784. doi:10.1016/S0140-6736(11)60993-8

7. Burstein HJ, Curigliano G, Loibl S, et al. Estimating the benefits of therapy for early stage breast cancer the st gallen international consensus guidelines for the primary therapy of early breast cancer 2019 . Ann Oncol. 2019;30(10):1541-1557. doi:10.1093/annonc/mdz235

8. Cardoso F, Kyriakides S, Ohno S, et al. Early breast cancer: ESMO clinical practice guidelines for diagnosis, treatment and follow-up. Ann Oncol. 2019;30(8):1194-1220. doi:10.1093/annonc/mdz173

9. Ruhstaller T, Giobbie-Hurder A, Colleoni M, et al. Adjuvant letrozole and tamoxifen alone or sequentially for postmenopausal women with hormone receptor-positive breast cancer: long-term follow-up of the BIG 1-98 trial. J Clin Oncol. 2019;37(2):105-114. doi:10.1200/ JCO. 18.00440

10. Pagani O, Regan MM, Walley BA, et al. Adjuvant exemestane with ovarian suppression in premenopausal breast cancer. $N$ Engl J Med. 2014;371:107-108. doi:10.1056/NEJMoa1404037

11. Metzger Filho O, Giobbie-Hurder A, Mallon E, et al. Relative effectiveness of letrozole compared with tamoxifen for patients with lobular carcinoma in the BIG 1-98 trial. J Clin Oncol. 2015;33 (25):2772-2779. doi:10.1200/JCO.2015.60.8133

12. Davies C, Pan H, Godwin J, et al. Long-term effects of continuing adjuvant tamoxifen to 10 years versus stopping at 5 years after diagnosis of oestrogen receptor-positive breast cancer: ATLAS, a randomised trial. Lancet. 2013;381:805-816. doi:10.1016/S01406736(12)61963-1

13. Goss PE, Ingle JN, Martino S, et al. Randomized trial of letrozole following tamoxifen as extended adjuvant therapy in receptor-positive breast cancer: updated findings from NCIC CTG MA.17. J Natl Cancer Inst. 2005;97:1262-1271. doi:10.1093/jnci/ dji250

14. Goss PE, Ingle JN, Pritchard KI, et al. Extending aromatase-inhibitor adjuvant therapy to 10 years. $N$ Engl $J$ Med. 2016;375:209-219. doi:10.1056/NEJMoa1604700

15. Colleoni M, Luo W, Karlsson P, et al. Extended adjuvant intermittent letrozole versus continuous letrozole in postmenopausal women with breast cancer (SOLE): a multicentre, open-label, randomised, Phase 3 trial. Lancet Oncol. 2018;19:127-138. doi:10.1016/S1470-2045(17) 30715-5

16. Chlebowski RT, Geller ML. Adherence to endocrine therapy for breast cancer. Oncol. 2006;71:1-9. doi:10.1159/000100444 
17. Hadji P. Improving compliance and persistence to adjuvant tamoxifen and aromatase inhibitor therapy. Critic Rev Oncol Hematol. 2010;73:156-166. doi:10.1016/j.critrevonc.2009.02.001

18. Dogrell SA. Adherence to oral endocrine treatments in women with breast cancer: can it be improved? Breast Cancer Res Treat. 2011;129:299-308. doi:10.1007/s10549-011-1578-z

19. Gotay C, Dunn J. Adherence to long-term adjuvant hormonal therapy for breast cancer. Expert Rev Pharmacoeco Outcomes Res. 2011;11 (6):709-715. doi:10.1586/erp.11.80

20. Verma S, Madarnas Y, Sehdev S, Martin G, Bajcar J. Patient adherence to aromatase inhibitor treatment in the adjuvant setting. Curr Oncol. 2011;18(Supplement 1):S3-S9. doi:10.3747/co.v18i0.899

21. Banning M. Adherence to adjuvant therapy in post-menopausal breast cancer patients: a review. Eur $J$ Cancer Care. 2012;21:10-19. doi:10.1111/j.1365-2354.2011.01295.x

22. Partridge AH, Wang PS, Winer EP, Avorn J. Nonadherence to adjuvant tamoxifen therapy in women with primary breast cancer. J Clin Oncol. 2003;21(4):602-606. doi:10.1200/JCO.2003.07.071

23. van Herk-sukel MPP, van Del Poll-franse LV, Voogd AC, Nieuwenhuijzen GAP, Coebergh JWW, Herings RMC. Half of breast cancer patients discontinue tamoxifen and any endocrine treatment before the end of the recommended treatment period of 5 years: a population-based analysis. Breast Cancer Res Treat. 2010;122:843-851. doi:10.1007/s10549-009-0724-3

24. Hershman DL, Kushi LH, Shao T, et al. Early discontinuation and nonadherence to adjuvant hormonal therapy in a cohort of 8769 early-stage breast cancer patients. $J$ Clin Oncol. 2010;28 (27):4120-4128. doi:10.1200/JCO.2009.25.9655

25. Cavazza M, Banks H, Ercolanoni M, et al. Factors influencing adherence to adjuvant endocrine therapy in breast cancer-treated women: using real-world data to inform a switch from acute to chronic disease management. Breast Cancer Res Treat. 2020;183:189-199. doi:10.1007/s10549-020-05748-6

26. Lash TL, Fox MP, Westrup JL, et al. Adherence to tamoxifen over the five-year course. Breast Cancer Res Treat. 2006;99(2):215-220. doi:10.1007/s10549-006-9193-0

27. Brett J, Boulton M, Fenlon D, et al. Adjuvant endocrine therapy after breast cancer: a qualitative study of factors associated with adherence. Patient Prefer Adherence. 2018;12:291-300. doi:10.2147/PPA.S145784

28. Ziller V, Kalder M, Albert US, et al. Adherence to adjuvant endocrine therapy in postmenopausal women with breast cancer. Ann Oncol. 2009;20:431-436. doi:10.1093/annonc/mdn646

29. Wassermann J, Gelber SI, Rosenberg SM, et al. Nonadherent behaviors among young women on adjuvant endocrine therapy for breast cancer. Cancer. 2019;125:3266-3274.

30. Yusufov M, Nathan M, Wiley A, et al. Predictors of increased risk for early treatment non-adherence to oral anti-estrogen therapies in early-stage breast cancer patients. Breast Cancer Res Treat. 2021;185:53-62.

31. He W, Fang F, Varnum C, Eriksson M, Hall P. Predictors of discontinuation of adjuvant hormone therapy in patients with breast cancer. J Clin Oncol. 2015;33(20):2262-2269. doi:10.1200/JCO.2014.59.3673

32. Pistilli B, Paci A, Ferreira AR, et al. Serum detection of nonadherence to adjuvant tamoxifen and breast cancer recurrence risk. J Clin Oncol. 2020;24:2762-2772. doi:10.1200/JCO.19.01758

33. Cahir C, Dombrowski SU, Kelly CM, Kennedy MJ, Bennett K, Sharp L. Women's experiences of hormonal therapy for breast cancer: exploring influences on medication-taking behaviour. Support Care Cancer. 2015;23(11):3115-3130. doi:10.1007/s00520-015-2685-X

34. Moon Z, Moss-Morris R, Hunter MS, Hughes LD. More than just side-effects: the role of clinical and psychosocial factors in nonadherence to tamoxifen. British $J$ Health Psychol. 2017;22 (4):998-1018. doi:10.1111/bjhp.12274

35. Vaughn J, Ammerman C, Stein J. Delay discounting as a predictor of adjuvant endo-crine therapy adherence among breast cancer survivors. J Clin Oncol. 2020;38(15):e24172-e24172.
36. Moon Z, Moss-Morris R, Hunter MS, Norton S, Hughes LD. Nonadher-ence to ta-moxifen in breast cancer survivors: a 12 month longitudinal analysis. Health Psychol. 2019;38(10):888-899. doi: $10.1037 /$ hea0000785

37. Pan Y, Heisig SR, von Blanckenburg P, et al. Facilitating adherence to endocrine therapy in breast cancer: stability and predic-tive power of treatment expectations in a 2-year prospective study. Breast Cancer Res Treat. 2018;168(3):667-677. doi:10.1016/j.pec.2004. 10.005

38. Fink AK, Gurwitz J, Rakowski W, Guadagnoli E, Silliman RA. Patient beliefs and Tamoxi-fen discontinuance in older women with estrogen receptor-positive breast cancer. J Clin Oncol. 2004;22 (16):3309-3315.

39. Cluze C, Rey D, Huiart L, et al. Adjuvant endocrine therapy with tamoxifen in young women with breast cancer: de-terminants of interruptions vary over time. Ann Oncol. 2012;23(4):882-890. doi:10.1093/annonc/mdr330

40. Kahn KL, Schneider EC, Malin JL, Adams JL. Patient centered experiences in breast cancer: predicting long-term adherence to tamoxifen use. Med Care. 2007;45(5):431-439.

41. Liu Y, Malin JL, Diamant AL, Thind A, Maly RC. Adherence to adjuvant hormone therapy in low-income women with breast cancer: the role of provider-patient communication. Breast Cancer Res Tr. 2012;137:829-836. doi:10.1007/s10549-012-2387-8

42. Chlebowski RT, Kim J, Haque R. Adherence to endocrine therapy in breast cancer adjuvant and prevention settings. Cancer Prev Res. 2014;7(4):378-387. doi:10.1158/1940-6207.CAPR-13-0389

43. Murphy CC, Bartholomew LK, Carpentier MY, Bluethmann SM, Vernon SW. Adherence to adjuvant hormonal therapy among breast cancer survivors in clinical practice: a systematic review. Breast Cancer Res Treat. 2012;134(2):459-478. doi:10.1007/s10549-0122114-5

44. McCowan C, Shearer J, Donnan PT, et al. Cohort study examining tamoxifen adherence and its relationship to mortality in women with breast cancer. Br J Cancer. 2008;99(11):1763-1768. doi:10.1038/sj. bjc. 6604758

45. Makubate B, Donnan PT, Dewar JA, Thompson AM, McCowan C. Cohort study of adherence to adjuvant endocrine therapy, breast cancer recurrence and mortality. $B r \quad J$ Cancer. 2013;108 (7):1515-1524. doi:10.1038/bjc.2013.116

46. Hershman DL, Shao T, Kushi LH, et al. Early discontinuation and non-adherence to adjuvant hormonal therapy are associated with increased mortality in women with breast cancer. Breast Cancer Res Treat. 2011;126(2):529-537. doi:10.1007/s10549-010-1132-4

47. Wheeler SB, Spencer J, Pinheiro LC, et al. Endocrine therapy non-adherence and discontinuation in black and white women. J Natl Cancer Inst. 2019;111(5):498-508. doi:10.1093/jnci/djy136

48. Neugut AI, Hillyer GC, Kushi LH, et al. Non-initiation of adjuvant hormonal therapy in women with hormone receptor-positive breast cancer: the breast cancer quality of care study (BQUAL). Breast Cancer Res Treat. 2012;134(1):419-428. doi:10.1007/s10549-012-2066-9

49. Montagna E, Pagan E, Bagnardi V, et al. Evaluation of endocrine therapy and patients preferences in early breast cancer: results of Elena study. Breast Cancer Res Treat. 2020;184:783-795. doi:10.1007/s10549-020-05900-2

50. Bergqvist J, Lundström S, Wengström Y, et al. Patient interactive digital support for women with adjuvant endocrine therapy in order to increase compliance and quality of life. Support Care Cancer. 2021;29(1):491-497. doi:10.1007/s00520-020-05476-z

51. Guth U, Huang DJ, Schotzau A, et al. Target and reality of adjuvant endocrine therapy in postmenopausal patients with invasive breast cancer. Br J Cancer. 2008;99:428-433. doi:10.1038/sj.bjc.6604525

52. Presant CA, Bosserman L, Young T, et al. Aromatase inhibitor-associated arthralgia and/or bone pain: frequency and characterization in non-clinical trial patients. Clin Breast Cancer. 2007;7 (10):775-778. doi:10.3816/CBC.2007.n.038 
53. Hewitt ME, Greenfield S, Stovall E. From cancer patient to cancer survivor: lost in transition. Washington, D.C: National Academies Press; 2006. Available from: http://www.nap.edu/catalog/114468.htlm.

54. Underwood M, Townsend JS, Stewart SL et al. Surveillance or demographic characteristics and health behaviors among adult cancer survivors-behavioral risk factor surveillance system, United States, 2009. centers for disease control and prevention (cdc) mmwr: morbidity and mortality weekly report. 2012; Available from: http:// www.cdc.gov/mmwr. Accessed August 3, 2021.

55. Bargon CA, Batenburg MCT, van Stam LE, et al. Impact of the COVID-19 pandemic on patient-reported outcomes of breast cancer patients and survivors. JNCI Cancer Spectr. 2020;5(1):pkaa104. doi:10.1093/jncics/pkaa104

56. Demissie S, Silliman RA, Lash TL. Adjuvant tamoxifen: predictors of use, side effects, and discontinuation in older women. $J$ Clin Oncol. 2001;19(2):322-328. doi:10.1200/JCO.2001.19.2.322

57. Grunfeld EA, Hunter MS, Sikka P, Mittal S. Adherence beliefs among breast cancer patients taking tamoxifen. Patient Educ Couns. 2005;59:97-102.

58. Ma AMT, Barone J, Wallis AE, et al. Noncompliance with adjuvant radiation, chemotherapy, or hormonal therapy in breast cancer patients. Am J Surg. 2008;196:500-504. doi:10.1016/j. amjsurg.2008.06.027

59. Owusu C, Buist DSM, Field TS, et al. Predictors of tamoxifen discontinuation among older women with estrogen receptor-positive breast cancer. J Clin Oncol. 2008;26(4):549-555. doi:10.1200/ JCO.2006.10.1022

60. Rae JM, Sikora MJ, Henry NL, et al. Cytochrome P450 2D6 activity predicts discontinuation of tamoxifen therapy in breast cancer patients. Pharmacogenomics. 2009;9(4):258-264. doi:10.1038/ tpj.2009.14

61. Dezentje VO, van Blijderveen NJC, Gelderblom H, et al. Effect of concomitant CYP2D6 inhibitor use and tamoxifen adherence on breast cancer recurrence in early-stage breast cancer. J Clin Oncol. 2010;28(14):2423-2429. doi:10.1200/JCO.2009.25.0894

62. Thompson AM, Johnson A, Quinlan P, et al. Comprehensive CYP256 genotype and adherence affect outcome in breast cancer patients treated with tamoxifen monotherapy. Breast Cancer Res Treat. 2011;125:279-287. doi:10.1007/s10549-010-11 39-x
63. Huiart L, Bouknik A, Rey D, et al. Early discontinuation of tamoxifen intake in younger women with breast cancer: is it time to rethink the way it is prescribed? Eur J Cancer. 2012;48(13):1939-1946. doi:10.1016/j.ejca.2012.03.004

64. Kimmick G, Anderson R, Camacho F, Bhosle M, Hwang W, Balkrishman R. Adjuvant hormonal therapy use among insured, low-income women with breast cancer. J Clin Oncol. 2009;27 (21):3445-3451. doi:10.1200/JCO.2008.19.2419

65. Schwartzberg LS, Cobb P, Senecal F, et al. Initial treatment and changes in adjuvant endocrine therapy for early stage breast cancer. Breast. 2009;18(2):78-83. doi:10.1016/j.breast.2009.01.002

66. Dittmer C, Roeder K, Hoellen F, Salehin D, Thill M, Fischer D. Compliance to adjuvant therapy in breast cancer patients. Eur J Gynecol Oncol. 2011;32(3):280-282.

67. Guth U, Myrick ME, Schotzau A, Kilic N, Schmid SM. Drug switch because of treatment-related adverse side effects in endocrine adjuvant breast cancer therapy: how often and how often does it work? Breast Cancer Res Treat. 2011;129:799-807.

68. Nekhlyudov L, Lingling L, Ross-Degnan D, Wagner AK. Five-year patterns of adjuvant hormonal therapy use, persistence, and adherence among insured women with early-stage breast cancer. Breast Cancer Res Treat. 2011;130:681-689. doi:10.1007/s10549-011-1703-z

69. Wigertz A, Ahlgren J, Holmqvist M, et al. Adherence and discontinuation of adjuvant hormonal therapy in breast cancer patients: a population-based study. Breast Cancer Res Treat. 2012;133 (1):367-373. doi:10.1007/s10549-012-1961-4

70. Weaver KE, Camacho F, Hwang W, Anderson R, Kimmick G. Adherence to adjuvant hormonal therapy and its relationship to breast cancer recurrence and survival among low-income women. Am J Clin Oncol. 2013;36(2):181-187. doi:10.1097/COC.0b013e3182436ec1

71. Corter, AL., Broom R, Porter D, Harvey V, Findlay M. (2018). Predicting nonadherence to adju-vant endocrine therapy in women with early stage breast cancer. Psycho-oncology. 2018;27(9): 20962103.
Patient Preference and Adherence

\section{Publish your work in this journal}

Patient Preference and Adherence is an international, peer-reviewed, open access journal that focusing on the growing importance of patient preference and adherence throughout the therapeutic continuum. Patient satisfaction, acceptability, quality of life, compliance, persistence and their role in developing new therapeutic modalities and compounds to optimize clinical outcomes for existing disease states are major areas of interest for the journal. This journal has been accepted for indexing on PubMed Central. The manuscript management system is completely online and includes a very quick and fair peer-review system, which is all easy to use. Visit http:/ www.dovepress.com/testimonials.php to read real quotes from published authors. 